\title{
IMPACT OF OPERATING CASH FLOW ON STOCK RETURNS
}

\author{
Bonifacius Parlin Sumarlin Malau', Ignatius Oki Dewa Brata² \\ Universitas Widyatama, Bandung ${ }^{1,2}$ \\ Email: bonifacius.parlin@widyatama.ac.id ${ }^{1}$, ignatius.oki@widyatama.ac.id ${ }^{2}$
}

\begin{abstract}
In this research, researchers aspire to examine the theory of whether there is a cash flow effect on stock changes. Stock returns which are used as stock measurement tools are a reflection of market reactions to what happens within the company in terms of fundamentals. Therefore to measure the fundamental factors that exist within the company researchers utilise operating cash flow. Operating cash flow is seen as being able to represent because operating cash flow data exists in every company. Moreover, hence that the comparison is balanced the researchers choose to use the population of companies in the $L Q 45$ area. After being tested using simple linear regression, the results are as previously thought that there are influences on the company's Fundamental factors which in this study is the Operating Cash Flow with market factors which in this study represented by Stock Return.
\end{abstract}

Keywords: financial statements, operating cash flow, stock return.

\section{INTRODUCTION}

Every company has its ability to build and develop its business. Companies can be assessed through the ability to generate profits, maintain investment value, and the company's ability to cope with company expenses that can be seen from the performance of the company's financial statements. According to Mulyadi (2001: 337) "Performance is the success of personnel, teams, or organisational units in realising strategic goals that have been set previously with the expected behaviour". In order for a company to be able to build and carry out its business, the company needs venture capital.

Azilia Yocelyna and Yulius Jogi Christiawan in 2012, which used the Accounting Profit and cash flow variables. The result of this study indicates that this study was conducted on 97 companies that have large capitalisation that was on the indoneisan market shared in 2009-2010. The result of the research concludes that 
the disclosure of Accounting Profit has a significant impact on Stock Return. Following is Nur Aini 2009 research that uses the same variable shows that from hypothesis testing, it presents findings that the Accounting Profit variable, ROA has a significant positive impact on Stock Return. Variable of Cash Flow from Operating Activities does not have a significant impact on Stock Return, while Cash Flow from investment activities and Cash Flow from funding activities have a significant positive impact on Stock Return, while the 2011 Seno Jodi Utomo study which uses the same variable shows that not all independent variables used in this study have a significant effect on Stock Return. Partially, Accounting Profit has a significant impact on Stock Return, while the Operating Cash Flow variable partially has no impact on Stock Return. However, Operating Cash Flow and Accounting Profit simultaneously have a positive and significant impact on Stock Return. Research of Sherlita (2016) with the results of gross profit affect the stock prices of goods and consumption industry companies listed on the Indonesia Stock Exchange in the period 2011-2014, while the total cash flow has no impact.

\section{FRAMEWORK}

According to Kiesso, Weygendt, Warflied (2007: 372) express their opinion that "Cash flow statement reports cash receipts, payments and net changes in cash from operating, investing and financing activities of a company during a period in a format recommending an initial and final cash balance". According to Skousen et al. (2009: 284), "cash flow statement themselves are financial statements that reports the amount of cash received and paid by a company during a certain period".In Statement of Financial Accounting Standards (PSAK) No.2, cash is defined as follow: "cash consists of cash balances (cash on hand) and checking accounts".

In the Statement of Financial Accounting Standards No.95, the FASB states that a report of cash flow statements must explain the difference between the initial balance and the final balance as well as cash equivalents, this means that in cash statements, cash has a broader understanding that is not only limited to the cash balance available at the company (cash on hand) and cash at the bank but also includes estimates known as cash equivalents. According to Horne and John (2012: 114) "Stock Return or commonly referred to as return is a payment received because of ownership rights, coupled with changes in market prices divided by initial prices". Brigham and Houston (2006: 215) state that "return or rate of return is the difference between the amount received and the amount invested".

Jogiyanto (2014: 263) states that return is the result obtained from an investment. Return can be in the form of Realized Return or Expected Return. Realised return 
is a return that has occurred, which is calculated based on historical data. Realised return is significant because it can be used as a measure of company performance. The expected return is the return that is expected to be obtained by investors in the future; therefore, the nature of the expected return has not happened yet, meanwhile according to Tandelilin (2010: 102). "Profit is something that is expected by investors in investing. The profits gained is the reward for the courage of investors in taking risks ". Operating cash flow can be used to determine the strengths and weaknesses of a company. Operating Cash Flow can also be used as an early warning signal of a setback in financial conditions by comparing with the previous year. Reports containing information contents that are important for an investor's investment decisions where if the company has adequate Operating Cash Flow, the condition of the company can be assumed to be financially stable therefore it will be responded well by investors.

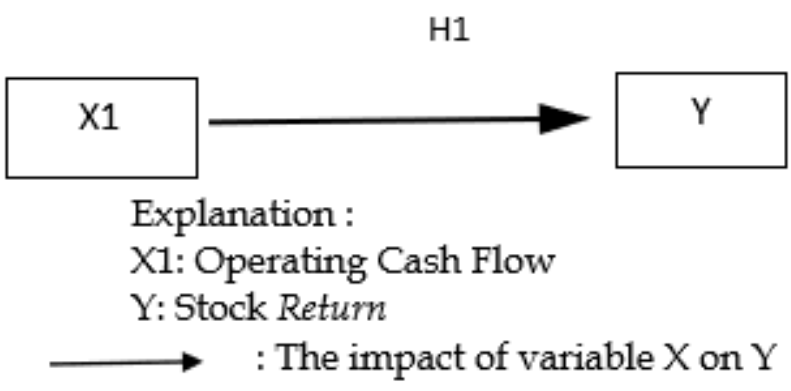

Figure 1. research paradigm

Following the theoretical foundation and the research model above and the available evidence, a hypothesis can be formulated which will be tested as follows:

H1: Operating Cash Flow has a positive impact on the LQ-45 company's Stock Return listed on the Indonesia Stock Exchange for the 2014-2018 period.

\section{METHOD}

Research methods can be interpreted as a scientific way to use data with specific purposes and uses. According to Sugiyono (2018: 02), four keywords need to be considered. The meaning of the research method is the sequence of data analysis processes that will be presented systematically, such as scientific method, data, purpose and usability.

1. The scientific way means that research activities are based on scientific characteristics, particularly rational, empirical, and systematic.

2. Rational means the research activities are carried out in ways that make sense, thus reachable by human observations.

3. Empirical means how human senses can observe it; therefore, others can observe and acknowledge the methods used. 
4. Systematic means the process used in the study uses specific logical steps.

In this study, the authors used a quantitative method, with a descriptive research approach and verification analysis. By using the research method, a significant effect between the variables studied will be known; therefore, the conclusions that will clarify the idea of the object under study. Quantitative research methods can be interpreted as research methods based on the philosophy of positivism, used to examine populations or specific samples, data collection using research instruments, quantitative/statistical data analysis, to test hypotheses that have been set (Sugiyono, 2016: 11 ).

The nature of this research is verification, a method that aims to test mathematically the allegations about the impact of the variable of the problem being investigated in a hypothesis in other words research to test the truth of a hypothesis where in this research the test will be operating cash flow on stock returns. The research design is a structural plan and strategy. As a plan and structure, the research design is a research plan, which is a detailed description of the entire research plan starting from the formulation of the problem, objectives, description of the relationship between variables, formulation of hypotheses to the design of data analysis, which is written down in the form of a research proposal or proposal Sugiyono (2016: 56). As a strategy, the research design is a detailed explanation of what the researcher will do in the context of conducting research. The research design used by the authors is a causal research design because the research method used explains the causal relationship; therefore, there are independent variables (which are influential) and dependent (influenced).

According to Sugiyono (2011: 38) states that the object of research is an attribute or nature or value of people, objects or activities that have individual variations determined by researchers to be examined and then the conclusions are drawn. In this research, the authors use a simple linear regression method, which is regression analysis used to predict how far the value change of the dependent variable, if the value of the independent variable is manipulated or changed or fluctuated.

According to Sugiyono (2018: 188), Linear regression is usually based on the functional or causal relationship of an independent variable with a dependent variable.

The general equation of simple linear regulation is:

Explanation:

$$
\mathrm{Y}=\mathrm{a}+\mathrm{b} \mathrm{X}+\mathrm{e}
$$

$\mathrm{Y}=$ The dependent variable is the purchase decision 
$A=$ price of $y$ if $X=0$ (constant)

$\mathrm{B}=$ number of regression coefficients which indicate the number of increase or decrease in the dependent variable based on the independent variable.

$\mathrm{X}=$ independent variable that is product quality.

$\mathrm{E}=$ Residual or Error

\section{FINDINGS AND DISCUSSION}

The LQ 45 index consists of 45 shares that have been selected through various selection criteria; thus, it will consist of shares with high liquidity and market capitalisation. Shares in the LQ 45 index must meet the criteria and pass the main selection as follows:

1. In the ranking of the top 60 of the total stock transactions on the regular market (average transaction value over the past 12 months). 2. Ranking based on market capitalisation (average market capitalisation during the last 12 months). 3. It has been listed on the JSE for a minimum of 3 months. 4. The financial situation of the company and its growth prospects, the frequency and number of days of regular market transaction trading. (factbook 1997, Jakarta Stock Exchange). Of the 45 shares included in LQ 45 from 2007 to 2011, 17 companies met the criteria and were included as research samples.

\section{Descriptive statistics}

Descriptive statistics is the science of statistics that studies the processes of collecting, compiling and presenting data for research. The aim is to make it easier for people to read the data and understand its purpose. The following is the spss output which is the entire data used in this study.

Table 1. Descriptive Statistics Table

\begin{tabular}{|c|c|c|c|c|c|}
\hline & $\mathbf{N}$ & Minimum & Maximum & Mean & Deviation Std. \\
\hline $\mathbf{X}$ & 30 & -1.53 & 5.37 & .5838 & 1.27998 \\
\hline $\mathbf{Y}$ & 30 & -.15 & .32 & .1003 & .12617 \\
\hline Valid N (listwise) & 30 & & & & \\
\hline
\end{tabular}

Source: Processed data

Operating cash flow is cash flow originating from operating activities mainly obtained from the main income activities of the company's income and other activities that are not investment activities and financing activities. The Operating Cash Flow method used is Operating Cash Flow, divided by the number of shares outstanding. According to Horne and John (2012: 114) "Stock Return or commonly referred to as return is a payment received because of ownership rights, coupled with changes in market prices divided by initial prices". Brigham and 
Houston (2006: 215) state that "return is the difference between the amount received and the amount invested".

\section{Discussion}

Before analysing statistical data, the authors try to explain the analysis relating to the data of each variable in this research, particularly the Operating Cash Flow variable (X), on Stock Return (Y). Analysis of the data in this research using multiple linear regression analysis methods or techniques. Regression analysis is a statistical technique that is useful for examining and modelling relationships among variables. Where the application of regression is generally associated with the study of the dependence of a variable (dependent variable) on other variables (independent variables). Whereas multiple linear regression analysis is generally used to analyse the relationship between two or more independent variables. To determine the impact of Operating Cash Flow (X) on Stock Return (Y). With the help of SPSS 17.00 software for Windows, the results can be seen in the following table:

Table 2. Table of Coefficients

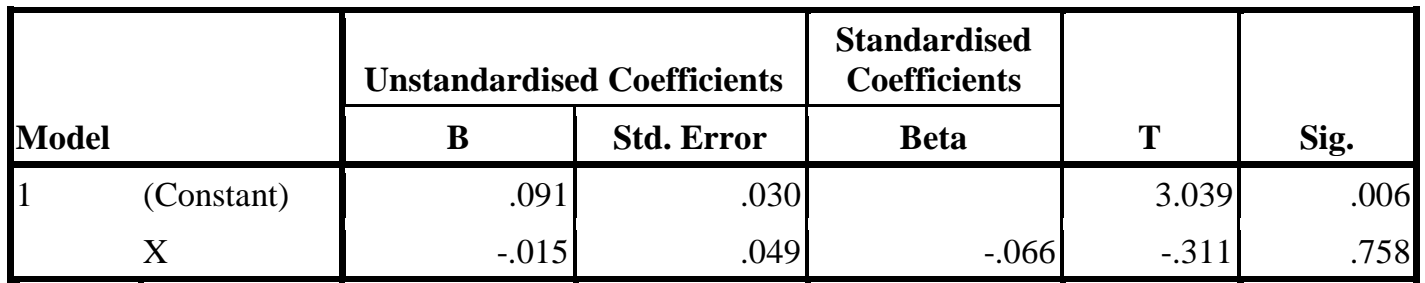

A. Dependent variable: $y$

Obtained are as follows.

$$
Y=0.091-0.015 X
$$

From the regression equation above, it can be seen that the regression coefficient (Bi) for the Operating Cash Flow variable (X1) is negative meaning that the variable hurts Stock Return (Y). Operating Cash Flow Variable (X), has a regression coefficient $(\mathrm{Bi})$ of -0.015 , this shows that each increase in the Operating Cash Flow variable (X), one unit of value will increase the Stock Return (Y) 0.015 unit of value, assuming the other variables are zero. To find out how much influence the variable Operating Cash Flow (X) on Stock Return (Y). Then the testing of the regression line will be performed through the hypothesis.

\section{Impact of Operating Cash Flow (X) on Stock Return (Y)}

Later it will be tested the impact of Operating Cash Flow (X) has a significant impact on Stock Return (Y) partially. The form of the hypothesis is as follows Ho: There is no influence of Operating Cash Flow (X), on Stock Return (Y). 
H1: There is an influence of Operating Cash Flow (X) on Stock Return (Y).The test statistic used to test the above hypothesis is the t-test. To find out the direct effect individually, a t-test must be performed first.

First, the t-value of each $X$ must be observed; afterwards, the $t_{\text {count }}$ value is compared with the $t$-value in the table. If the value of $t_{\text {count }}$ is higher than the $t_{\text {table }}$ value, then the hypothesis is significant, meaning that the effect that occurs can be generalised to the entire population. Conversely, if the value of $t_{\text {count }}$ is smaller

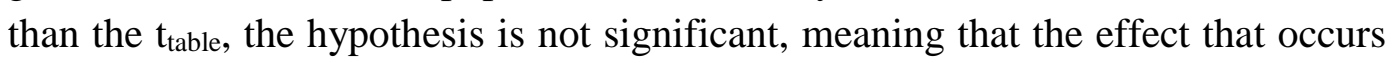
cannot be generalised to the entire population. Based on the results of data processing, as shown in the Coefficients table, the $t_{\text {count }}$ value is obtained.

Table 3. Table of Coefficients

\begin{tabular}{|c|c|c|c|c|c|}
\hline \multirow[b]{2}{*}{ Model } & \multicolumn{2}{|c|}{ Coefficients un-standardised } & $\begin{array}{l}\text { Coefficients } \\
\text { standardised }\end{array}$ & \multirow[b]{2}{*}{$\mathbf{T}$} & \multirow[b]{2}{*}{ Significant } \\
\hline & B & Eror standart & Beta & & \\
\hline Constan & .091 & .030 & & 3.039 & .006 \\
\hline$X$ & -.015 & .049 & -.066 & -.311 & .758 \\
\hline
\end{tabular}

A. Dependent variable: $y$

From the Coefficients table above, it can be concluded as stated in the tcount table of each independent variable as below. While the score of $t_{\text {table }}$ is the distribution of t-student at the real level $(\alpha) 5$ Percentage with a free degree of 23 . The conclusions that can be drawn are as follows:

Tabel 4 .Table of Individual Testing Conclusions Table

\begin{tabular}{|c|c|c|c|}
\hline Variable & $\begin{array}{c}\text { Value of } \\
\mathbf{t}_{\text {count }}\end{array}$ & Value of $\mathbf{t}_{\text {table }}$ & Conclusion \\
\hline $\mathrm{X}$ & 0.311 & 1.74 & Not significant \\
\hline
\end{tabular}

Source: calculation result

From the table above it can be described the independent not affect dependent variable. Also, the effect cannot be generalised to the entire population.

\section{CONCLUSION}

This study aims to determine how much partial influence of operating cash flow on stock returns of companies on the Indonesia market share in the 2014-2018 period. Based on the description of the theory and analysis that has been done, the researchers conclude that the company that has the most massive Operating Cash Flow is PT Indofood Sukses Makmur Tbk which occurred in 2018 while the smallest operating cash flow is PT Bank Rakyat Indonesia (Persero) Tbk. Which happened in 2016. The company that has the most significant stock return is PT AKR Corporindo Tbk which occurred in 2014 while the smallest Stock Return 
April, 2020

was PT Tambang Batubara Bukit Asam Tbk., which happened in 2017. Operating Cash Flow affects the Stock Return.

\section{REFERENCES}

Azilia Yocelyna dan Yulius Jogi Christiawan. (2012). "Analisis Pengaruh Perubahan Arus Kas dan Laba Akuntansi Terhadap Return Saham pada Perusahaan Berkapitalisasi Besar". Jurnal. Universitas Kristen Petra Surabaya.

Brigham, Eugene dan Joel F. Houston. (2006). Dasar-dasar Manajemen Keuangan. Edisi Kesepuluh. Jakarta: Salemba Empat.

Horne, James C. Van dan John M Wachowicz, Jr. (2012). Prinsip-prinsip Manajemen Keuangan. Edisi 13. Jakarta : Salemba Empat.

Ikatan Akuntan Indonesia. (2009). Standar Akuntansi Keuangan. Jakarta: Salemba Empat.

Jogiyanto, Hartono. (2014) .Teori Portofolio dan Analisis Investasi. (Edisi Kelima). Yogyakarta: BPFE UGM.

Kieso, Weygandt, dan Warfield. (2002). Akuntansi Intermediate. (Edisi Kesepuluh). Jakarta: Erlangga.

Mulyadi. (2001). Sistem Akuntansi. (Edisi Ketiga, Cetakan Ketiga). Jakarta: Salemba Empat.

Nur Aini. (2009). "Pengaruh Laba Dan Komponen Arus Kas terhadap Return Saham (Studi Empiris Pada Perusahaan Terdaftar Di Bei Periode Tahun 2007-2009)". Jurnal ISSN. Universitas Stikubank Semarang.

Skousen, Smith. (2001). Akuntansi Intermediate, Volume Komprehensif, Jilid 2, Edisi Sembilan. Jakarta: Erlangga.

Seno Jodi Utomo. (2011). “Analisis Pengaruh Arus Kas Operasi Dan Laba Akuntansi Terhadap Return Saham Perusahaan Manufaktur Di Bursa Efek Indonesia”. Jurnal. Universitas Negeri Semarang.

Sherlita, Erly. (2016). Pengaruh Laba Kotor Dan Total Arus Kas Terhadap Harga Saham. Jurnal Akuntansi Bisnis dan Ekonomi. Volume 2 No. 1.

Sugiyono. (2011). Metode Penelitian Kuantitatif Kualitatif dan R\&D (12 thed). Bandung: Alfabeta. 